\title{
TIME REDUCTION EFFECT OF THE ENHANCED TACT METHOD FOR HIGH-RISE RESIDENTIAL BUILDINGS
}

\author{
Donghoon LEE ${ }^{\mathrm{a}}$, Dong-Sub KIM ${ }^{\mathrm{b}}$, Gwang-Hee KIMc, Sunkuk KIM ${ }^{\mathrm{a}}$ \\ ${ }^{a}$ Department of Architectural Engineering, Kyung Hee University, Gyeonggi-do, Republic of Korea \\ ${ }^{b}$ Department of Building Construction Technology Team, Daelim Industrial CO., \\ Ltd., Seoul, Republic of Korea \\ ${ }^{c}$ Department of Architectural Engineering, Kyonggi University, Gyeonggi-do, Republic of Korea
}

Received 23 Oct 2013; accepted 22 May 2014

\begin{abstract}
The finish work on high-rise residential buildings is performed simultaneously with mechanical and electrical construction work, which results in frequent work interference and delay. This significantly hinders efficient schedule management. Critical Path Method (CPM) is inefficient when applied to high-rise residential building projects in which work is repeatedly carried out for each floor. Line-of-Balance (LOB) is widely used for its effectiveness in managing repetitive work. LOB was developed into TACT and eTACT (enhanced-TACT) to combine heterogeneous works continuously. In particular, the eTACT schedule management method has an advantage in that it is capable of systematically connecting detailed construction, mechanical and electrical construction projects using a work planning template. This study evaluates the time reduction effect of the eTACT method for a high-rise residential building. A comparative analysis of data on 102 cases of non-applied projects and 44 cases of projects using the eTACT method over a period of 10 years is presented to verify its effectiveness. The result shows that finish work time was reduced by $25 \%$ or about 53 days on average.
\end{abstract}

Keywords: time reduction effect, finish work, TACT, residential building, schedule management.

\section{Introduction}

Most high-rise residential buildings are constructed similarly on each floor or in zones which have similar floor plans. These works are broken down into smaller works (Sacks, Goldin 2007; Cho et al. 2013). Finish work is carried out simultaneous with mechanical and electrical construction work. Such works are repeated at each floor, resulting in complicated interconnections. Furthermore, as the repeat count increases, the waiting time due to work interference will increase (Al-Momani 2000). For this reason, various studies have been conducted with Critical Path Method (CPM), Line-of-Balance (LOB) and other methods (Suhail, Neale 1994; Yamín, Harmelink 2001; Arditi, Albulak 1986). Among these methods, the most common is the CPM. The significance of CPM in the construction industry is recognized because it is systematic and detailed (Kim 2012); however, it is difficult to modify its logic and is inefficient for repetitive works (Rahbar, Rowings 1992). CPM is also unsuitable for high-rise residential buildings since the productivity of workers is not taken into consideration (Selinger 1980). In particular, it is not helpful for simplifying progress management, which requires significant effort and time.
The LOB method is efficient at analyzing repetitive works (Al Sarraj 1990); however, it is difficult to manage works that involve the interaction of several schedules (Arditi et al. 2002) which affects waiting time. In addition, LOB and other existing methods do not reflect the subcontractor's scheduling management (Choi 2012). For efficient scheduling of high-rise residential buildings, resource levelling is necessary (Cho et al. 2013). To this end, TACT and eTACT methods that combine LOB, value stream analysis and the new scheduling concept of Lean Construction are being studied (Kim et al. 2003; Suh et al. 2003). Lee et al. (2004) well introduced the TACT scheduling method that serves to synchronize the cycle time of repetitive works by zoning the work places and maintaining each work with the proper number of workers, so there is less waiting time for the crews.

The concept of TACT is to reduce work time by consistently repeating the works of precedence relationship. However, it is difficult to realize time reduction without details of the TACT method. The eTACT method systematically combines detailed construction and mechanical and electrical construction projects, applying the work planning template to the existing TACT method. It is ex-

Corresponding author: Sunkuk Kim

E-mail:kimskuk@khu.ac.kr 
pected that this process will closely connect heterogeneous works, reducing the wait time.

This study evaluates the time reduction effect of the eTACT method. To do so, the enhanced-TACT (eTACT) method was applied to high-rise residential buildings, and the data on construction time were collected. The eTACT method can be applied to a wide range of finished works with different sequences and methods, yet the study scope is limited to residential buildings. The study is conducted in three different steps. First, the scheduling methods of repetitive works are examined, the concept of eTACT scheduling method is established and the procedure for applying the method is identified. Second, the eTACT method is applied to large residential buildings for a period of 10 years. Third, the data of work duration on highrise residential buildings applied with the eTACT method and those not applying the method within the same firm are compared to verify the time reduction effect.

\section{Preliminary study}

\subsection{Line of Balance (LOB)}

LOB maintains the productivity of each crew for repetitive work, and the productivity is expressed as a gradient of a line to mark the progress of each repetitive work. This method allows efficient schedule management by schematizing the overall work (Arditi, Albulak 1986; Arditi, Psarros 1987). Numerous studies have been conducted for efficient management of LOB. Arditi et al. (2002) incorporated the concept of a learning curve effect with the existing LOB method to suggest a plan to reflect the time reduction effect of improved productivity. Authors analyzed several repetitive works and removed all unnecessary manpower and materials input based on the learning effect in the paper, arguing that productivity improvement and time reduction effects are realized. Soini et al. (2004) used DYNAProject ${ }^{\mathrm{TM}}$, a resource-based LOB operating software that enables application of LOB method to general construction, in order to improve quality of the schedule, minimize risks and reduce overall construction cost. Sacks and Goldin (2007) proposed the Lean
Apartment Construction Simulation Game (LEAPCON), a computer simulation method to improve the work in progress based on the LOB method and the lean model.

However, LOB method has limitations on the expression of specific interfaces among work trades performed in a certain space or floor as shown in Figure 1. For example, finish works, such as masonry, plastering, waterproofing and painting works, have different characteristics in variety, quantity, working circulation and productivity of their subdivided activities. And some finish works are interruptively conducted with mechanical and electrical works at the same space. The more work trades are involved, the more interruptions among subdivided activities may occur. In this case, LOB method has limitation on the expression of critical activities that can happen among subdivided activities. Figure 1 (1) shows the example of interfaces among work trades, and Figure 1 (2) illustrates the details of interfaces among subdivided activities that shows critical path. The eTACT can make up for limitations of the LOB method with work planning templates introduced in Chapter 2.

\section{2. eTACT scheduling method}

In most of the cases, at least two work trades are carried out simultaneous to the finish work for a high-rise apartment building. Around $45 \%$ of the finish work time turned out to be non-work time caused by work interference (Kim et al. 2003). To resolve this problem, the TACT schedule management method was adopted. The TACT scheduling method divides the work zone (Cho et al. 2013) based on the LOB, and the work time is unified, continuing the precedence relationship (Yoon, Suh 2005).

The TACT method defines each work in detail and plans and manages the defined work so that those with a precedence relationship are consistently linked, which will make the work more effective and will shorten the waiting time between projects to reduce the overall construction time (Kim et al. 2003).

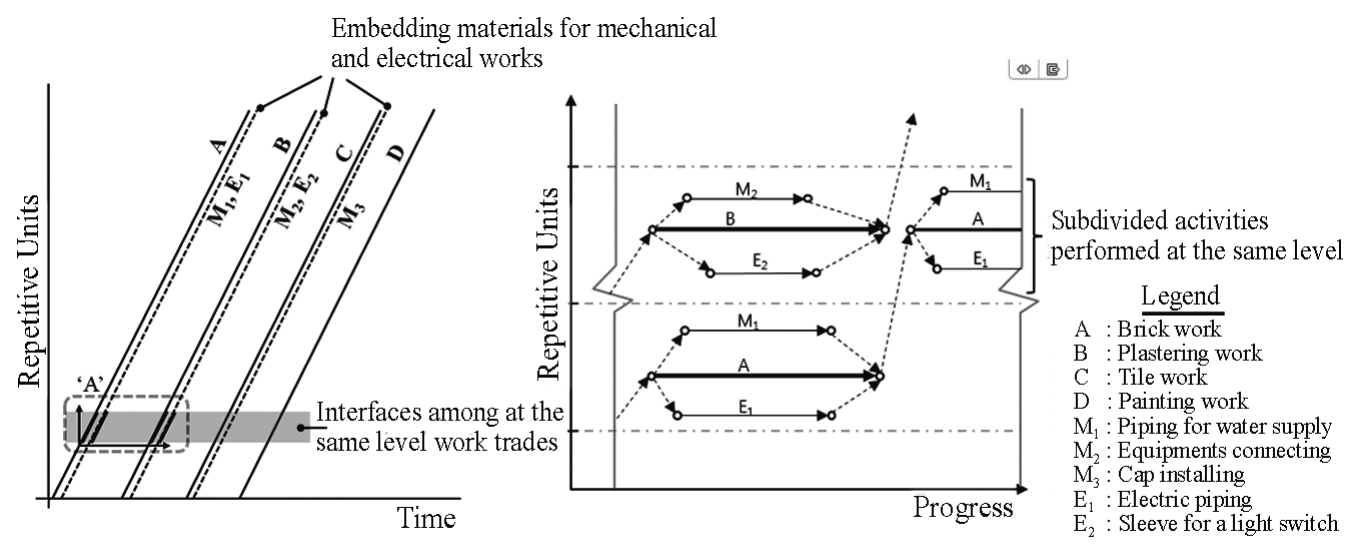

(1) Interfaces among work trades

(2) Interfaces among subdivided activities (Detail 'A')

Fig. 1. Interfaces among work trades 


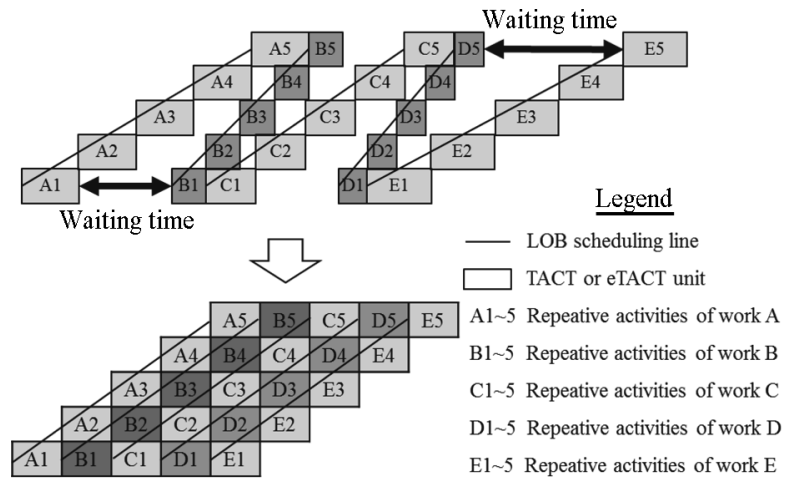

Fig. 2. Waiting time between work trades

Figure 2 shows the concept of adjusting the time of the prior TACT unit and the post TACT unit, so that the same duration of both TACTs can be seen. Six days are set for the TACT unit, and the work time of the activity included in the TACT unit is adjusted so that all TACT units are scheduled for works that last 6 days. This concept ensures work continuity and becomes the basis for progress management.

As shown in Table 1 below, the LOB, TACT and eTACT scheduling methods have some difference in terms of scheduling target, activity control, work load of each activity, waiting time between work trades, cooperation among relevant subcontractors, description of critical path and scheduling technique. TACT was devised to make up for limitations of LOB (Lee et al. 2004), and eTACT is proposed for more efficient management of TACT in this paper. Basically, LOB, TACT and eTACT are conducted by the linear scheduling technique, but eTACT is supplemented with work planning template. TACT and eTACT are suggested to eliminate waiting time between work trades under close cooperation among

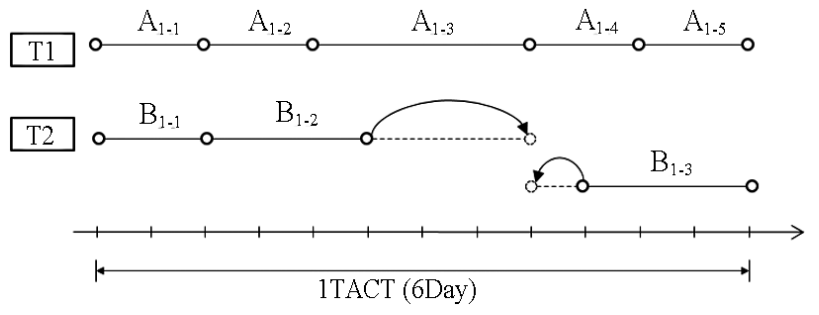

Fig. 3. Concept of controlling TACT units

subcontractors as shown in Figure 2 while waiting time often happens in the LOB method. TACT and eTACT serve to synchronize the cycle time of repetitive works by allocating uniform workload. The eTACT method describes critical paths with activities subdivided half-daily on work planning templates while the LOB and TACT methods control are difficult to describe a critical path and control activities daily.

In the case of TACT unit 1 (T1) shown in Figure 3, the work time of $\mathrm{A}_{1-5}$ is reduced, and in the case of TACT unit 2 (T2), the work times of $B_{1-2}$ and $B_{1-3}$ are increased to 6 days. Based on the work efficiency, the manpower input will be controlled (Kim et al. 2011). Adjusting the manpower input is necessary for a specific crew to perform the work without interruption.

However, the TACT method lacks details to control the detailed work, making it difficult to apply to highrise residential building projects. Until the early 2000s, large construction firms tried to adopt the TACT method, but little progress had been made. Moreover, the TACT method overlooked the low probability that a worker who finished a given activity and is off site for a certain period of time will come back for the next activity (Kim et al. 2011). In other words, a worker outside the site may not come back on time or such a worker may be replaced with another worker, reducing the work efficiency. It is

Table 1. Comparison of LOB, TACT and eTACT

\begin{tabular}{|c|c|c|c|}
\hline Description & LOB & TACT & eTACT \\
\hline Scheduling target & $\begin{array}{l}\text { - Repetitive works for each } \\
\text { work trade } \\
\text { - Less consideration between } \\
\text { work trades }\end{array}$ & $\begin{array}{l}\text { - Repetitive works for each } \\
\text { work trade } \\
\text { - Close consideration among } \\
\text { work trades }\end{array}$ & $\begin{array}{l}\text { - Repetitive works for each work trade } \\
\text { - Close consideration among subdivided } \\
\text { activities of each work trade }\end{array}$ \\
\hline $\begin{array}{l}\text { Activity } \\
\text { control }\end{array}$ & $\begin{array}{l}\text { - Divided by floor under } \\
\text { different time span of each } \\
\text { work trade } \\
\text { - Controlled daily }\end{array}$ & $\begin{array}{l}\text { - Divided by floor under same } \\
\text { time span of each work trade } \\
\text { - Controlled daily }\end{array}$ & $\begin{array}{l}\text { - Divided by floor under same time } \\
\text { span of each work trade } \\
\text { - Subdivided to detail activities and } \\
\text { controlled half-daily on work } \\
\text { planning templates }\end{array}$ \\
\hline Workload & Variable & Uniform & Uniform \\
\hline Waiting time & $\begin{array}{l}\text { Waiting time often happens } \\
\text { between work trades }\end{array}$ & $\begin{array}{l}\text { No or less waiting time happens } \\
\text { between work trades }\end{array}$ & $\begin{array}{l}\text { No or less waiting time happens } \\
\text { between work trades }\end{array}$ \\
\hline $\begin{array}{l}\text { Cooperation among } \\
\text { subcontractors }\end{array}$ & $\begin{array}{l}\text { General cooperation needs } \\
\text { among subcontractors }\end{array}$ & $\begin{array}{l}\text { Close cooperation needs among } \\
\text { subcontractors. }\end{array}$ & $\begin{array}{l}\text { Close cooperation needs among } \\
\text { subcontractors }\end{array}$ \\
\hline Critical path & Difficult to describe & Difficult to describe & $\begin{array}{l}\text { Described on work planning } \\
\text { templates }\end{array}$ \\
\hline $\begin{array}{l}\text { Scheduling } \\
\text { technique }\end{array}$ & Linear scheduling method & Linear scheduling method & $\begin{array}{l}\text { Linear scheduling method }+ \text { work } \\
\text { planning template }\end{array}$ \\
\hline
\end{tabular}




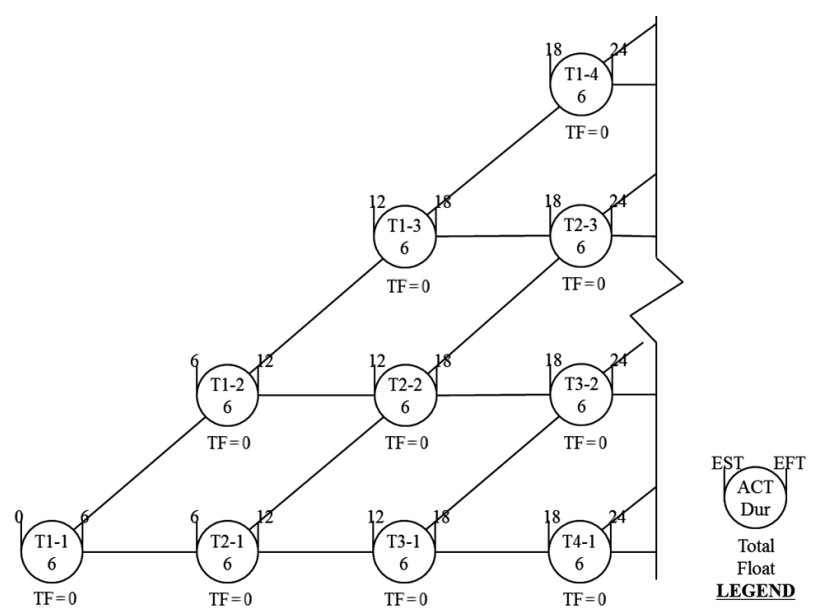

Fig. 4. Continuity of work between eTACT units

an important managerial delay factor (Kazaz et al. 2012). Thus, the work time is adjusted to consider the efficiency of unit work for the TACT application. Also, detailed work should be scheduled so that workers do not leave the site but continue the given work.

To do so, the work planning template is adopted. The eTACT method secures the continuity of activities to reduce the waiting time caused by the difference in work pace. In addition, continuous work will reduce the risk that is likely when securing the required manpower. When this concept is applied to the repetitive unit, the continuity of work can be achieved by applying the same work time per repetitive 6 day unit, as shown in Figure 4.

A single eTACT unit that covers 6 days is composed of around 10 20 finish, mechanical and electrical works. In addition, there is no float time in between the eTACT units, so when the synchronized work is delayed, it will greatly impact the overall work time. Thus, there is a possibility of restrictions on space and time due to simultaneous works being performed by several subcontractors as well as work interference. These problems can be solved using a thorough plan on detailed works. The eTACT method uses a work planning template for detailed work plans.

\section{2. eTACT: Work planning template}

The "work planning template" of eTACT should be prepared by analyzing in detail the work interference that may be generated during the actual work on site and considering the precedence relationship with heterogeneous works. The eTACT scheduling method is applied to represent the works within the eTACT unit in detail. In other words, by 0.5 day/activity, the work planning template classifies activities subdivided in the eTACT unit, including mechanical work and electricity/communications construction work, and the critical path are analyzed by the respective work experts. Then, the precedence relationship with the heterogeneous work is analyzed after discussion with other work experts. In addition, the critical work trades are selected from all the simultaneously performed works, and interference, including spatial restrictions that may be generated when the work is carried out in a limited space, is analyzed (Kim et al. 2011).

As shown in Figure 5, the work planning template arranges the critical works in order. These critical works impact the post work in the eTACT unit cycle, so intensive management is required. Also, the works are classified into three different fields - construction work, mechanical work and electricity/communications construction work - to represent the precedence relationship within the same construction work. This makes it possible to identify the relation with the heterogeneous works. Furthermore, the spatial interference that may be generated due to progress in the work can be identified.

Among the case projects, the work planning template prepared in accordance with a 6 day eTACT schedule is shown in Figure 5. As demonstrated in the work planning template, ceiling work is completed within 6 days, from level check to cleaning, with the work continuity secured.

\begin{tabular}{|c|c|c|c|c|}
\hline DAY & Critical Path & Finish work & Mechanical work & Electrical work \\
\hline 0.5 & Level checking $\left(A_{1.1}\right)$ & Level checking $\left(A_{1-1}\right)$ & Bath tub installing $\left(M_{1}\right)$ & \\
\hline 1.0 & Lamp box/curtain box $\left(A_{1-2}\right)$ & Lamp box'curtain box $\left(\mathrm{A}_{1-2}\right)$ & \multirow{4}{*}{$\begin{array}{l}\text { Piping for ventilation \& } \\
\text { Aircon. } \\
\left(\mathrm{M}_{2}\right)\end{array}$} & Lamp wiring $\left(E_{2}\right)$ \\
\hline 1.5 & Circuit test $\left(\mathrm{E}_{2}\right)$ & Scaffold $\left(A_{1-3}\right)$ & & Circuit test $\left(\mathrm{E}_{2}\right)$ \\
\hline 2.0 & \multirow{4}{*}{$\begin{array}{l}\text { Ceiling board } \\
\left(A_{1.4}\right)\end{array}$} & \multirow{4}{*}{$\begin{array}{l}\text { Ceiling board } \\
\left(A_{1-4}\right)\end{array}$} & & \\
\hline 2.5 & & & & \\
\hline 3.0 & & & Equipments & \\
\hline 3.5 & & & connecting $\left(\mathrm{M}_{3}\right)$ & \\
\hline 4.0 & \multirow{2}{*}{ Ceiling carpentry $\left(A_{1-s}\right)$} & \multirow{2}{*}{ Ceiling carpentry $\left(A_{1-s}\right)$} & \multirow{2}{*}{ Hydraulic test $\left(\mathrm{M}_{4}\right)$} & \\
\hline 4.5 & & & & \\
\hline 5.0 & \multirow{2}{*}{ Ceiling molding $\left(A_{1.6}\right)$} & \multirow{2}{*}{ Ceiling molding $\left(A_{1.6}\right)$} & \multirow{2}{*}{$\begin{array}{l}\text { Sprinkler head and } \\
\text { grill }\left(\mathrm{M}_{5} \sim \mathrm{M}_{6}\right)\end{array}$} & \\
\hline 5.5 & & & & \\
\hline 6.0 & Cleaning $\left(\mathrm{M}_{7}\right)$ & Cleaning $\left(A_{7}\right)$ & Cap installing $\left(\mathrm{M}_{7}\right)$ & \\
\hline
\end{tabular}

Fig. 5. An example of work planning templates 


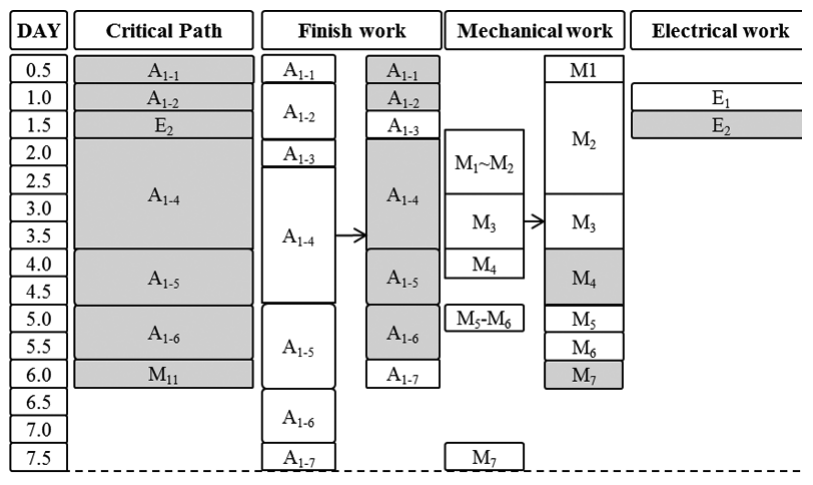

Fig. 6. Work planning template adjusted by crews

Figure 6 shows the process of setting the pace and time of the given work by adjusting the manpower input for preparation of the work planning template of the ceiling work. When the ceiling work is in progress, the mechanical work and the construction work will be performed in combination. As an initial schedule, the construction work is expected to last for 7.5 days, and the mechanical work has 4 days of waiting time in accordance with the construction work plan. To ensure work continuity, the manpower input for the construction work is increased to reduce the work time to 6 days, and the manpower input for the mechanical work is adjusted to from two crews to one to reduce man-hours of waiting.

When preparing the work planning template, the precedence relationship should be considered along with the work continuity. As shown in Figure 7, the critical pass of the detailed construction and mechanical and electrical works should be managed separately (1).

Furthermore, the order should be marked to clearly represent the precedence relationship of each work (4), (5)). For instance, in the case of electrical work, " $E_{2}$ " (2), (3) should be performed after the " $\mathrm{A}_{1-2}$ " activity is completed and should be completed before " $\mathrm{A}_{1-4}$ " so that the given construction work is not delayed.

The mechanical work within the eTACT unit is performed by two teams, as shown in Figure 8. The me-

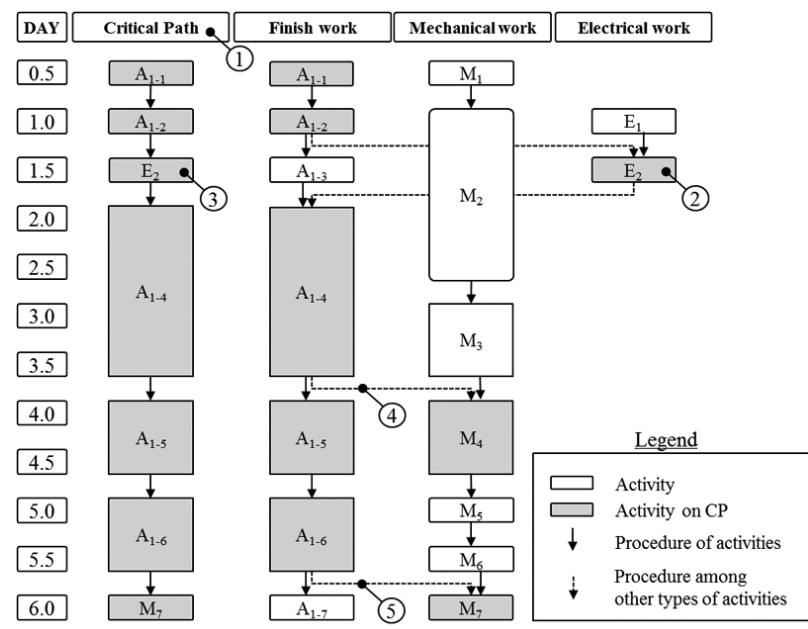

Fig. 7. Setting up the precedence relationship

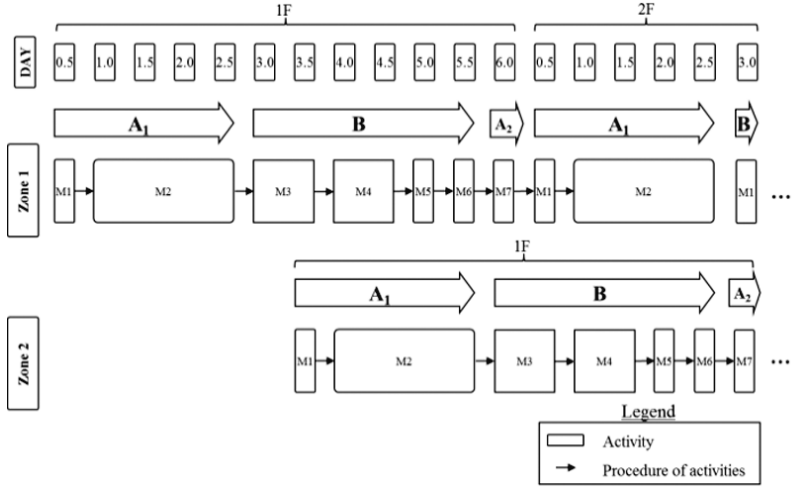

Fig. 8. Setting up the relationship between eTACT units

chanical team performs the plumbing and other works for 2.5 days $\left(\mathrm{A}_{1}\right)$, and the sprinkler team is dispatched after the plumbing work is completed to carry out a hydraulic test and connect the sprinkler heads (B). Finally, the general mechanical team performs the finish work for 0.5 days $\left(\mathrm{A}_{2}\right)$. For continuous works of two teams, the sprinkler work is scheduled to be performed alternately in two zones. In other words, six days are required for eTACT unit management, and the detailed works are divided into zones according to the work load, scheduled for two or three days.

When preparing the work planning template, the manpower input is adjusted based on the productivity. Table 2 shows the productivity estimated based on data for a large global construction firm in Korea for the past 10 years. The data in Table 2 are used for preparing the work planning template of the project with the eTACT method. Based on the work team and daily work load, the input crews can be adjusted to control the work time.

\section{Methodology}

\subsection{Statistical methods}

For verification of the time reduction effect of the eTACT method, the actual data of 44 residential buildings con-

Table 2. Productivity rate of finish works

\begin{tabular}{|c|c|c|c|}
\hline Work & Crew & Unit & $\begin{array}{c}\text { Daily } \\
\text { Productivity }\end{array}$ \\
\hline Masonry & Skilled labour: 1 & Brick & $2,000 / \mathrm{man}$ \\
\hline $\begin{array}{l}\text { Lightweight } \\
\text { panel }\end{array}$ & $\begin{array}{l}\text { Skilled labour: } 1 \\
\text { Common labour: } 2\end{array}$ & $\mathrm{M}^{2}$ & $30 /$ crew \\
\hline $\begin{array}{l}\text { Lightweight AE } \\
\text { concrete work }\end{array}$ & Skilled labour: 5 & $\mathrm{M}^{3}$ & $70 /$ crew \\
\hline Floor plastering & $\begin{array}{l}\text { Concrete worker: } 4 \\
\text { Plastering worker: } 5\end{array}$ & $\mathrm{M}^{2}$ & $1,500 /$ crew \\
\hline Wall plastering & Skilled worker: 1 & $\mathrm{M}^{2}$ & $30 / \operatorname{man}$ \\
\hline Wall tiling & $\begin{array}{l}\text { Skilled worker: } 1 \\
\text { Common labour: } 1\end{array}$ & $\mathrm{M}^{2}$ & 20/crew \\
\hline Floor tiling & Skilled worker: 1 & $\mathrm{M}^{2}$ & $20 /$ man \\
\hline Ceiling & $\begin{array}{l}\text { Skilled worker: } 1 \\
\text { Common labour: } 1\end{array}$ & $\mathrm{M}^{2}$ & $120 /$ crew \\
\hline
\end{tabular}


ducted by a local construction firm were collected over the past 10 years. In addition, 102 cases that did not apply the eTACT method for the same period were examined to conduct the ANOVA test of construction duration. Every project of two groups was independently conducted, and construction duration of the project is a quantitative variable. The difference of construction duration between two groups is examined by one-way ANOVA test due to the existence of single independent variable for comparison. The Levene's test and t-test between two groups are conducted to examine the distribution of collected data, which is used for a clue of solving the productivity issue.

\subsection{Variable control of ANOVA test}

For more accurate verification of the time reduction effect of the eTACT method against non-application of the method, other variables that may affect time reduction, including ease of supplying workers, managing the ability of firms, work duration and details, and other external delay factors are excluded. First, the same conditions apply for supplying workers and for project management in order to minimize the effect on work time. In addition, the duration change caused by development of construction technologies for the projects performed in the same period is controlled. Since the work time differs according to the construction type, projects with the same finish work are the study subjects. Finally, works under special conditions, such as suspension of the given work and design changes, are excluded from the comparison analysis. The description of each variable control is as follows:

1) Worker supply: It is not difficult to supply workers in Korea, since labors are abundant in urban areas. Thus, the case study is carried out on projects implemented in urban areas with population of at least 1 million persons;

2) Unification of managing ability: The managing ability and system differ by firm, and this may impact the work time. Therefore, the eTACT method is applied to a large construction firm that constantly implements numerous housing projects, and cases of the same firm not employing eTACT are used for comparison;

3) Restriction of the duration of project implementation: The cases applying the eTACT method are executed in 2002 2011, and the non-eTACT cases are examined from projects implemented within the same range of years;

4) Restriction of the construction details: If the finish work type differs, it may lead to different work times. Our study is restricted to residential buildings built with the same finishing materials, as shown in Table 3;

5) Restrictions on external delay factors: External delay factors, including suspension of the given work and design changes, may distort the result. Thus, projects with these delay factors are excluded from the case study. Delay caused by external factors is not likely
Table 3. Finish work of a housing unit in this study

\begin{tabular}{llll}
\hline & Floor & Wall & Ceiling \\
\hline $\begin{array}{l}\text { Living } \\
\text { room }\end{array}$ & $\begin{array}{l}\text { Ondol heating } \\
\text { system + Wood } \\
\text { flooring }\end{array}$ & $\begin{array}{l}\text { Wall } \\
\text { paper }\end{array}$ & $\begin{array}{l}\text { Gypsum board } \\
+ \text { paper }\end{array}$ \\
\hline Bedroom & $\begin{array}{l}\text { Ondol heating } \\
\text { system + Vinyl sheet }\end{array}$ & $\begin{array}{l}\text { Wall } \\
\text { paper }\end{array}$ & $\begin{array}{l}\text { Gypsum board } \\
+ \text { paper }\end{array}$ \\
\hline Bathroom & $\begin{array}{l}\text { Ondol heating } \\
\text { system + Ceramic } \\
\text { tile }\end{array}$ & Wall tile & $\begin{array}{l}\text { Unit plastic } \\
\text { ceiling }\end{array}$ \\
\hline Kitchen & $\begin{array}{l}\text { Ondol heating } \\
\text { system + Wood } \\
\text { flooring }\end{array}$ & $\begin{array}{l}\text { Wall } \\
\text { paper }\end{array}$ & $\begin{array}{l}\text { Gypsum board } \\
+ \text { paper }\end{array}$ \\
\hline
\end{tabular}

during the finish work, and no such case occurred in this study.

The productivity of finish work is mainly affected by the evolution of material, equipment, technology and management. Among the factors, material, equipment and technology evolved over the past 10 years are considered to be equally applied to two groups of collected data, which may not affect the productivity of finish work. However, management technique has been evolved from the LOB to the eTACT method, which may affect the productivity.

To prove the assumption, the distribution of yearly collected data is surveyed as shown in Figure 9. The figure shows comparatively consistent distribution although the numeric difference between two groups happens. And statistically, the equality of variances can be confirmed by the Levene's test result of two groups that shows 0.116 of $\mathrm{F}$ value and 0.734 of $\mathrm{P}$ value which means the distribution of collected data statistically acceptable as shown in Table 4.

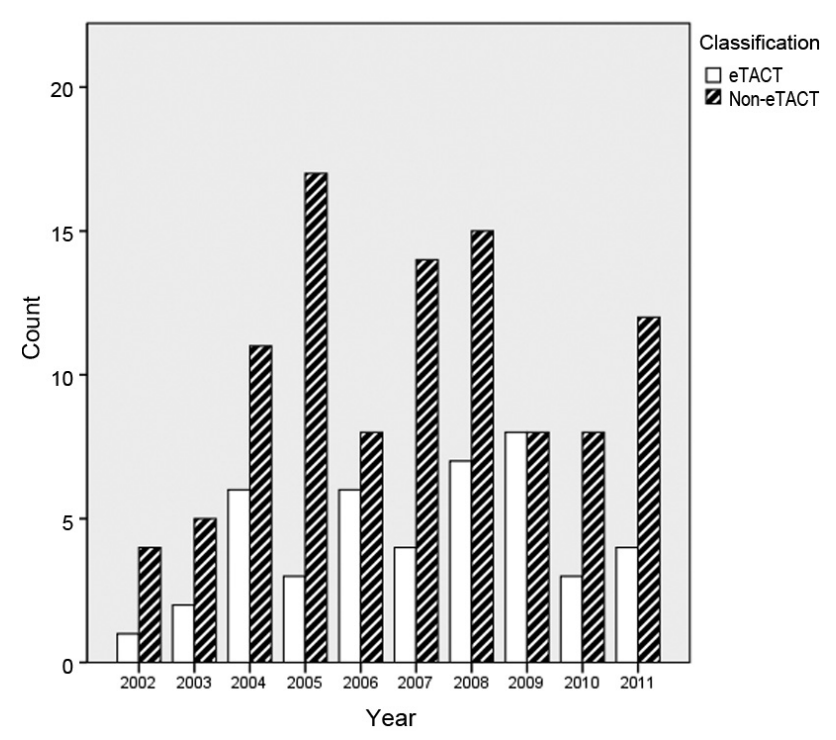

Fig. 9. Distribution of yearly collected data 
Table 4. Levene's test result of two groups

\begin{tabular}{llllll}
\hline \multirow{2}{*}{ Classification } & \multicolumn{3}{c}{ Statistics } & \multicolumn{2}{c}{ Levene's test } \\
\cline { 2 - 4 } & $\mathrm{N}$ & Mean & $\begin{array}{l}\text { Std. } \\
\text { Deviation }\end{array}$ & F & Sig. \\
\hline eTACT & 44 & 2007.11 & 2.452 & 0.116 & 0.734 \\
\hline Non-eTACT & 102 & 2006.88 & 2.565 & & \\
\hline
\end{tabular}

\section{Finish work time of the top floor}

To compare the construction time of collected data, Figure 10 is presented. Finish work in the Figure 10 includes all works such as floor, wall, and ceiling finish works after structural work. The finish work time (a) influencing on the total project duration (c) is the duration for completing the finish work of the top floor right after structural work as shown in the Case 1 of Figure 10. Although, as shown in the Case 2 of Figure 10, the total finish work time (b') increases according to the increase of the number of floors, the finish work time (a) for the top floor only influences on the total project duration (c') as the same as Case 1. In other words, the increase of structural work time only affects the total project duration (c'). Therefore, if the total construction time needs to be shorter under the fixed time condition of structural work, finish work time of the top floor should be reduced with management efficiency.

In general, the increase of workload, herein building floor area for finish work, may affect the increase of work time, which is acceptable in case of arranging same work crews for the work trades that have different workloads. However, in case of arranging more work crews for bigger workloads of work trades, the workloads may not affect the durations of finish works, which is confirmed from the analysis of the data collected over the past 10 years. Table 5 shows the statistics of workloads and durations of collected data.

Table 5. Statistics of workload and duration

\begin{tabular}{llll}
\hline & Mean & Std. Deviation & $\mathrm{N}$ \\
\hline Workload $\left(\mathrm{m}^{2}\right)$ & 393.3389 & 122.84917 & 146 \\
\hline Duration (day) & 191.7671 & 34.63744 & 146 \\
\hline
\end{tabular}

Table 6. Correlation of workload and duration

\begin{tabular}{llcc}
\hline & & Workload & Duration \\
\hline \multirow{3}{*}{ Workload } & Pearson Correlation & 1 & -0.094 \\
\cline { 2 - 4 } & Sig. (2-tailed) & & 0.258 \\
\cline { 2 - 4 } & $\mathrm{N}$ & 146 & 146 \\
\hline \multirow{2}{*}{ Duration } & Pearson Correlation & -0.094 & 1 \\
\cline { 2 - 4 } & Sig. (2-tailed) & 0.258 & \\
\cline { 2 - 4 } & $\mathrm{N}$ & 146 & 146 \\
\hline
\end{tabular}

Table 6 shows the correlation of workload, herein finish work area of the top floor, and duration. The correlation of two groups is -0.94 , which means that the workload doesn't affect the duration of the work. As a result, it is assumed that the enhanced scheduling method like eTACT only affects the time reduction of the top floor finish work.

\section{Analysis of the time reduction effect}

Table 7 tabulates the descriptive statistics for both the eTACT and non-eTACT data. The duration for the group applying the TACT method is relatively lower than the one for the group not applying the eTACT method. The data show the number of floors in a building, the total floor area and the top floor finish work duration. Table 3 shows the cases applying the eTACT method, and the top floor work duration ranges from 130 days to 185 days. As mentioned previously, all data are from the same firm, and the location, finishing type and so forth are controlled. The top floor work duration of the study subjects ranges from 170 days to 262 days.

The difference in the duration of finish work between group 1, which applied the eTACT method, and group 2, which did not apply the eTACT method are examined. It is notable that the sample means for the two groups were not numerically identical, as shown in Table 5. However, it is difficult to conclude that this difference is meaningful. The Analysis of Variance (ANOVA) test determines whether the numerical difference between two sample means is statistically significant (Walpole et al. 1993). Therefore, evidence exists of the differences between the
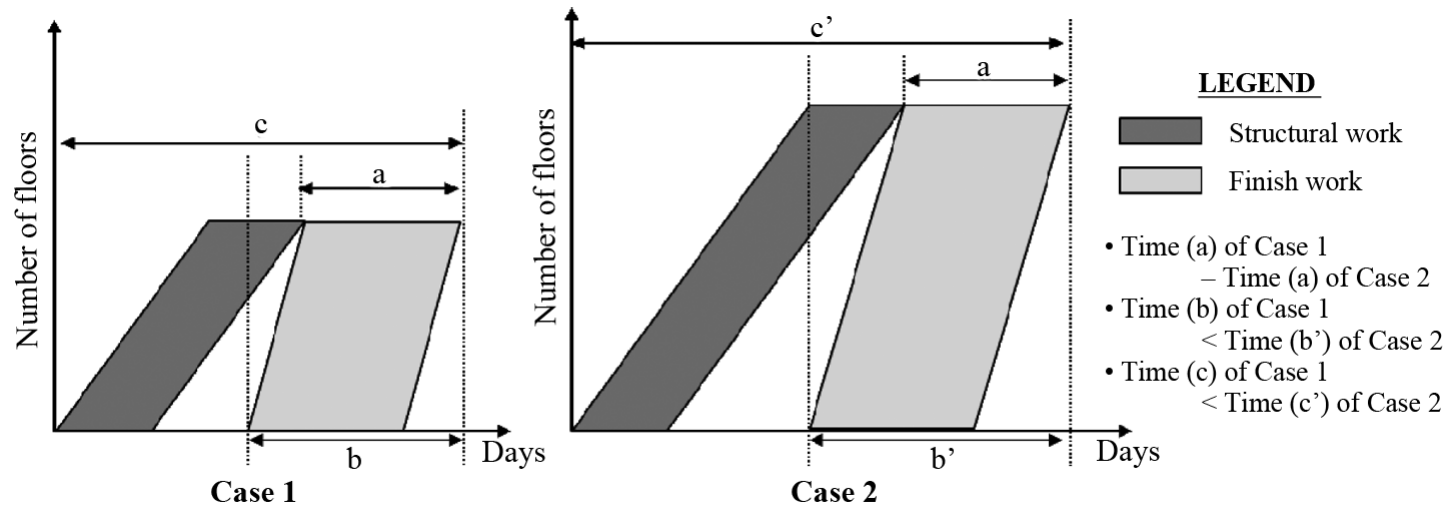

Fig. 10. Finish work time of the top floor 
Table 7. Descriptive statistics of collected data

\begin{tabular}{|c|c|c|c|c|c|c|c|c|}
\hline & \multirow{2}{*}{$\mathrm{N}$} & \multirow{2}{*}{ Mean } & \multirow{2}{*}{$\begin{array}{c}\text { Std. } \\
\text { Deviation }\end{array}$} & \multirow{2}{*}{$\begin{array}{l}\text { Std. } \\
\text { Error }\end{array}$} & \multicolumn{2}{|c|}{ 95\% Confidence Interval for Mean } & \multirow{2}{*}{ Min. } & \multirow{2}{*}{ Max. } \\
\hline & & & & & Lower Bound & Upper Bound & & \\
\hline eTACT & 44 & 153.06 & 20.541 & 3.096 & 146.8229 & 159.3135 & 130.0 & 185.0 \\
\hline Non-eTACT & 102 & 208.31 & 24.450 & 2.420 & 203.5112 & 213.1162 & 170.0 & 262.0 \\
\hline Total & 146 & 191.66 & 34.475 & 2.853 & 186.0251 & 197.3037 & 130.0 & 262.0 \\
\hline
\end{tabular}

population means. The hypotheses for this ANOVA problem are as follows:

$$
\begin{aligned}
& \mathrm{H}_{0}: \mu_{\mathrm{T}}=\mu_{\mathrm{N}} ; \\
& \mathrm{H}_{1}: \mu_{\mathrm{T}} \neq \mu_{\mathrm{N}},
\end{aligned}
$$

here, $\mu_{T}$ is the mean of the work time of the residential buildings to which the eTACT method was applied, and $\mu_{N}$ is that of the residential buildings to which the eTACT method was not applied. To confirm the outliers of the two samples, a box plot was adopted as shown in Figure 11. There were no outliers found in the eTACT applied cases or the non-applied cases.

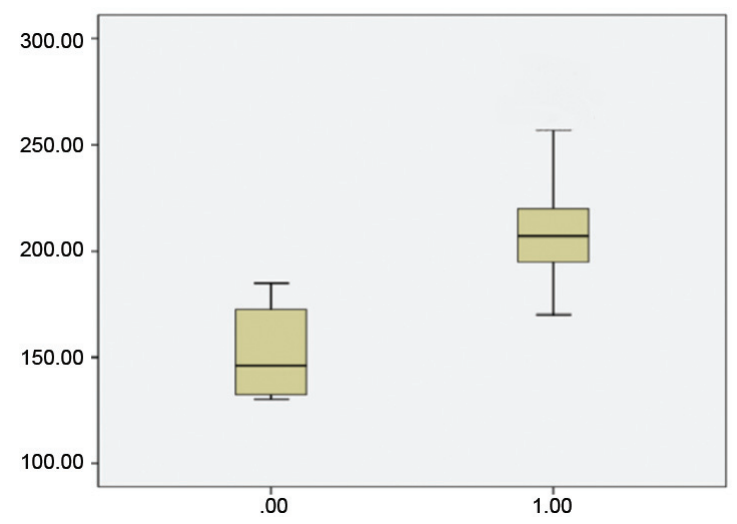

Fig. 11. Box plot for differences

\section{Findings and results}

The $\mathrm{F}$ test results are shown in Table 8 . The variance of the data to determine the difference between two group means can be analyzed by an F test, which provides the p-value. Based on the p-value, the hypotheses above are tested. Through the F test, if the between-group variability is larger than the within-group variability, $\mathrm{H}_{0}$ could be rejected, i.e., it could be concluded that the means of the two groups are statistically different (Walpole et al. 1993).

The study applied the eTACT method to residential buildings to verify the time reduction effect. The top floor finish work duration applied with the eTACT method for 10 years was 153 days on average and 206.2 days for the non-applied cases. Moreover, the F-Test result of the case data shows that the mean values of the two groups are significant at the $95 \%$ confidence interval level. The difference in work time was caused by the delay

Table 8. Statistical results of eTACT and non-eTACT data

\begin{tabular}{lccccc}
\hline & $\begin{array}{c}\text { Sum of } \\
\text { Squares }\end{array}$ & df & $\begin{array}{c}\text { Mean } \\
\text { Square }\end{array}$ & F & Sig. \\
\hline $\begin{array}{l}\text { Between } \\
\text { Groups }\end{array}$ & 93819.799 & 1 & 93819.799 & 172.048 & 0.000 \\
Within & 78524.756 & 144 & 545.311 & & \\
$\begin{array}{l}\text { Groups } \\
\text { Total }\end{array}$ & 172344.555 & 145 & & & \\
\hline
\end{tabular}

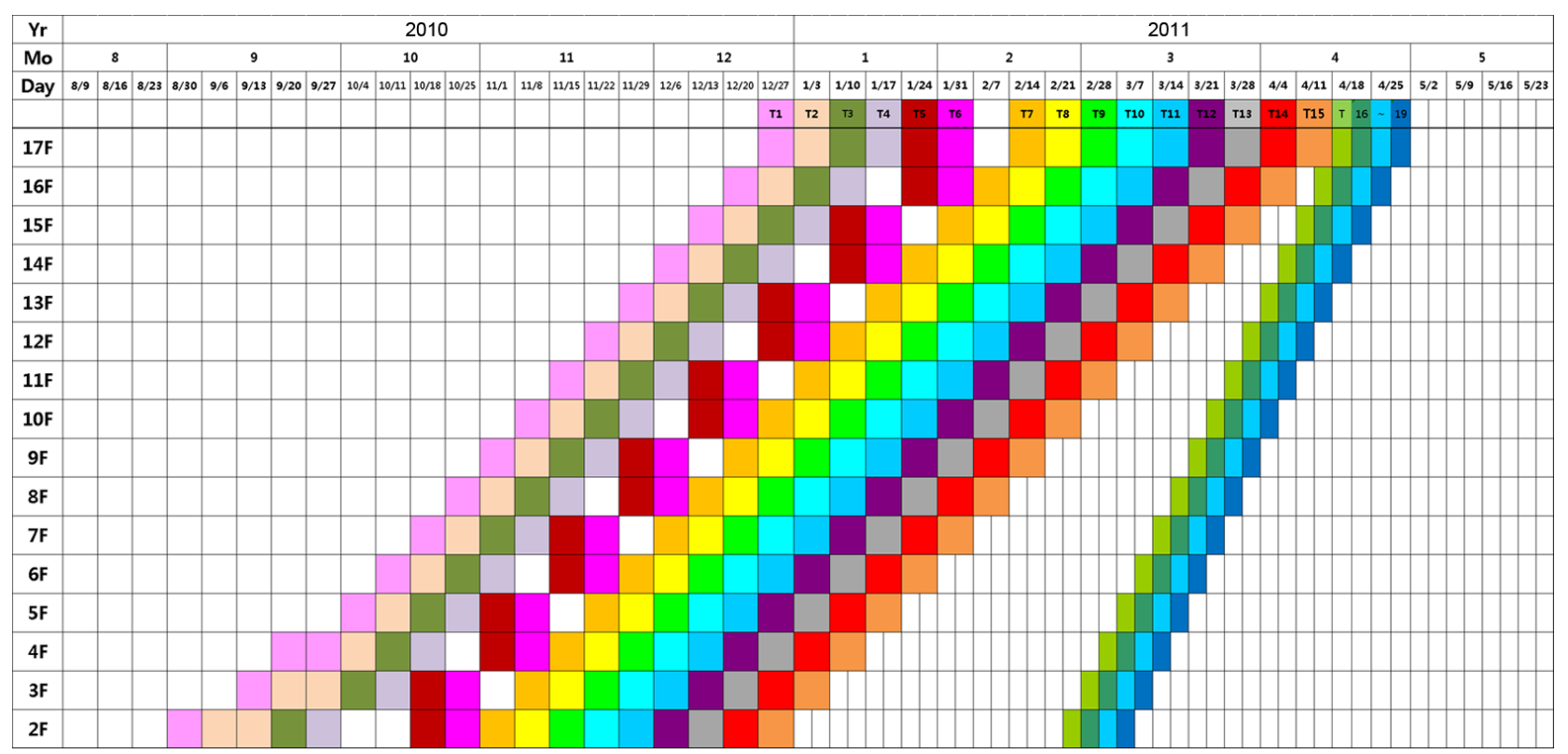

Fig. 12. An example of the eTACT scheduling method 


\begin{tabular}{|c|c|c|c|c|c|c|c|c|c|c|c|c|c|}
\hline$\varphi_{r}$ & \multicolumn{12}{|c|}{2004} & \multirow{2}{*}{$\begin{array}{c}2005 \\
1 \\
\end{array}$} \\
\hline Mo & 1 & 2 & 3 & 4 & 5 & 6 & 7 & 8 & 9 & 10 & 11 & 12 & \\
\hline PH2 & & & & & & & & & & & & & \\
\hline PH1 & & & & & & & & & & & & & \\
\hline $15 \mathrm{~F}$ & & & & & & & & & & & 4 & & \\
\hline $14 \mathrm{~F}$ & & & & & & & & & & & & & \\
\hline $13 F$ & & & & & & & & & & & & & \\
\hline $11 \mathrm{~F}$ & & & & & & & & & & & & & \\
\hline $10 \mathrm{~F}$ & & & & & & & & & & & & & \\
\hline $9 \mathrm{~F}$ & & & & & & & & & & & & & \\
\hline $7 \mathrm{~F}$ & & & & & & & & & & 7 & & & \\
\hline $6 F$ & & & & & & & & & & & & & \\
\hline $5 F$ & & & & & & & & & & & & & \\
\hline $4 \mathrm{~F}$ & & & & & & & & & & & & & \\
\hline $\begin{array}{l}3 \mathrm{~F} \\
\end{array}$ & & & & & & & & & & & & & \\
\hline $1 \mathrm{~F}$ & & & 1 & & & & & & 1 & & & & \\
\hline PIT & & & & & & & & & & & & & \\
\hline
\end{tabular}

Fig. 13. An example of the linear scheduling method

in executing the works in progress, as previously stated (Fig. 2), and this can be identified in the progress schedule of the case. Figure 12 shows the progress schedule of the eTACT-applied case with a short work time, and all finish works were performed without waiting or delay. The work time of this project data was 130 days.

Figure 13 shows a case without eTACT and with a relatively short work time. It is one of the progress schedule of finish works in non-eTACT data. All finish works were performed in order without delay, and the top floor work duration was 180 days. The work time is longer than that with the eTACT method because there is a waiting time caused by the pace difference of the works in progress, as shown in Figure 13 (c) and (d). In addition, Figure 13 (a) is the air entrained concrete pouring work, which delayed the post floor plastering work, Figure 13 (b), for about 15 20 days due to the change in the pace of work. These waiting time and work delays are commonly found in cases not applying eTACT. This seems to be caused by the mean difference of the two samples.

Finally, the productivity data used for eTACT in this study are based on the experiences of the given firm, and they were not verified, which may result in slight errors. However, such errors may be commonly found in all samples and should not affect the finish work duration. Furthermore, it was assumed that there is no productivity difference between eTACT cases and non-eTACT cases, so the effects of using the eTACT method should be studied in the future.

\section{Conclusions}

Scheduling the finish work of high-rise residential building projects significantly affects the overall work time. The study examined the scheduling methods applied to high-rise residential building projects, defined the concept of eTACT and applied it to the case projects.
The eTACT method is applied to unify works per eTACT unit to perform the works continuously and to minimize the float. The method involves preparing a work planning template to control the activity time. Furthermore, the eTACT scheduling method is applied to show the work within the eTACT unit in detail, in other words to prepare activities in 0.5 day increments. The works within the eTACT unit are composed of construction and mechanical and electrical communication construction works, and the precedence relationship of the same work and the critical path are analyzed by work experts. Then, the precedence relationship with the heterogeneous work is analyzed upon discussion with other work experts. In addition, critical work trades are selected from all the simultaneously performed works, and interferences, including the spatial restriction that may be generated when the work is carried out in the limited space, are reflected. Based on this, the final work planning template for work continuity is prepared to commence the work.

The study verified the time reduction effect of the eTACT method. The mean finish work duration was 153 days for the case with eTACT and 206.2 days without, for a difference of 53 days. Time to completion with the eTACT method decreased by around $25 \%$ when compared to conventional LOB. Also, five variables including the region, work type, worker supply, management ability and application time of the given cases were controlled to conduct the F-test. As a result, there was a significant mean difference in the two groups at the $95 \%$ confidence interval level. Based on the result, the progress schedules of the cases were analyzed, and it was discovered that the difference in work time is caused by the delay and waiting time of the (prior/post) works in progress. When this method is applied to high-rise residential buildings, the impacts of work delay and waiting time will increase, improving the time reduction effect. As follow-up studies, the productivity of unit works with the eTACT method 
should be analyzed, which is expected to improve the time reduction effect of eTACT.

\section{Acknowledgements}

This work was supported by the National Research Foundation of Korea (NRF) grant funded by the Korea government (MSIP) (No. 2013R1A2A2A01068297).

\section{References}

Al Momani, A. H. 2000. Construction delay: a quantitative analysis, International Journal of Project Management 18(1): 51-59. http://dx.doi.org/10.1016/S0263-7863(98)00060-X

Al Sarraj, Z. M. 1990. Formal development of line-of-balance technique, Journal of Construction Engineering and Management 116(4): 689-704.

http://dx.doi.org/10.1061/(ASCE)0733-9364(1990)116:4(689)

Arditi, D.; Albulak, M. Z. 1986. Line-of-balance scheduling in pavement construction, Journal of Construction Engineering and Management 112(3): 411-424.

http://dx.doi.org/10.1061/(ASCE)0733-9364(1986)112:3(411)

Arditi, D.; Psarros, M. K. 1987. SYRUS-system for repetitive unit scheduling, in Proc. of the Nordnetinternet-PMI 87 Conference, 1987, Verkfnastjornum, The Icelandic Project Management Society. 7 p.

Arditi, D.; Tokdemir, O. B.; Suh, K. 2002. Challenges in Lineof-Balance scheduling, Journal of Construction Engineering and Management 128(6): 545-556.

http://dx.doi.org/10.1061/(ASCE)0733-9364(2002)128:6(545)

Choi, J. 2012. A knowledge representation model for formalizing subcontractors' scheduling process, Journal of Asian Architecture and Building Engineering 11(2): 275-282. http://dx.doi.org/10.3130/jaabe.11.275

Cho, K.; Hong, T.; Hyun, C. T. 2013. Space zoning conceptbased scheduling model for repetitive construction process, Journal of Civil Engineering and Management 19(3): 409421. http://dx.doi.org/10.3846/13923730.2012.757561

Kazaz, A.; Ulubeyli, S.; Tuncbilekli, N. A. 2012. Causes of delays in construction projects in Turkey, Journal of Civil Engineering and Management 18(3): 426-435. http://dx.doi.org/10.3846/13923730.2012.698913

Kim, S. G. 2012. CPM schedule summarizing function of the Beeline Diagramming Method, Journal of Asian Architecture and Building Engineering 11(2): 367-374. http://dx.doi.org/10.3130/jaabe.11.367
Kim, Y. J.; Han, J. Y.; Shin, D. W.; Kim, K. R.; Kim, C. D.; Seo, S. W. 2003. A Tact Planning and Scheduling Process Model for reduction of finishing work duration in building construction projects, Journal of the Architectural Institute of Korea 19(1): 161-168.

Kim, S. K.; Son, K. Y.; Joo, J. K.; Lee, D. H.; Lee, S. H. 2011. An enhanced TACT technique for finish work of high-rise residential buildings, Journal of Korea Institute of Building Construction 11(4): 396-406. http://dx.doi.org/10.5345/JKIBC.2011.11.4.396

Lee, H. S.; Yu, J. H.; Kim, S. K. 2004. Impact of labor factors on workflow, Journal of Construction Engineering and Management 130(6): 918-923.

http://dx.doi.org/10.1061/(ASCE)0733-9364(2004)130:6(918)

Rahbar, F. F.; Rowings, J. E. 1992. Repetitive activity scheduling process, Transactions of the American Association of Cost Engineers O.5.1-O.5.8.

Sacks, R.; Goldin, M. 2007. Lean management model for construction of high-rise apartment buildings, Journal of Construction Engineering and Management 133(5): 374-384.

http://dx.doi.org/10.1061/(ASCE)0733-9364(2007)133:5(374)

Selinger, S. 1980. Construction planning for linear projects, Journal of the Construction Division 106(2): 195-205.

Soini, M.; Leskelä, I.; Seppänen, O. 2004. Implementation of line-of-balance based scheduling and project control system in a large construction company, in The $12^{\text {th }}$ Annual Conference on Lean Construction, 3-5 August 2004, Helsingør, Denmark, 1-11.

Suh, S. W.; Kim, J. H.; Kim, S. K.; Kim, C. H.; Lee, H. S. 2003. Development and application of TACT management system, Journal of Korea Construction Engineering \& Management 4(4): 145-154.

Suhail, S. A.; Neale, R. H. 1994. CPM/LOB: New methodology to integrate CPM and line of balance, Journal of Construction Engineering and Management 120(3): 667-684.

http://dx.doi.org/10.1061/(ASCE)0733-9364(1994)120:3(667)

Walpole, R. E.; Myers, R. H.; Myers, S. L.; Ye, K. 1993. Probability and statistics for engineers and scientists, Vol. 8. Upper Saddle River, NJ: Prentice Hall. 816 p.

Yamín, R. A.; Harmelink, D. J. 2001. Comparison of linear scheduling model (LSM) and critical path method (CPM), Journal of Construction Engineering and Management 127(5): 374-381.

http://dx.doi.org/10.1061/(ASCE)0733-9364(2001)127:5(374)

Yoon, Y. S.; Suh, S. W. 2005. The application of tact time at finish work for building construction - focused on office building, Journal of Korean Construction Engineering and Management 6(6): 90-97.

Donghoon LEE. He is a $\mathrm{PhD}$ candidate of the Department of Architectural Engineering at Kyung Hee University. He received the professional engineer's license of building construction in 2012. His research interests include the construction engineering and management, particularly the cost and time management of buildings, the production technology of free-form concrete segments and the crane management with support design.

Dong-Sub KIM. He is a leader of building construction technology team at Daelim Industrial Co., Ltd. He has served as a field engineer and a cost and schedule engineer since 1995. He received the professional engineer's license of building construction in 2004. His research interests include the cost and time management, particularly the practical application of TACT scheduling method in site.

Gwang-Hee KIM. He is the associate professor of the Department of Plant \& Architectural Engineering at Kyonggi University. He was a vice president of the Korea Institute of Building Construction. He is currently the editor-in-chief of the Journal of Building Construction and Planning Research. His research interests are in the areas of cost estimating, data mining, building information modelling, green construction, and construction information technology.

Sunkuk KIM. He is a leader of the innovative construction technology and management system. Currently, he has served as a vice director of the Centre for Sustainable Healthy Buildings and a vice president of Korean Council on Tall Buildings and Urban Habitat (K-CTBUH). His research interests include the construction engineering and management issues, particularly the development of innovative practical construction technologies such as the Green Frame, a sustainable environment-friendly structure, and the production technology of free-form concrete segments. 